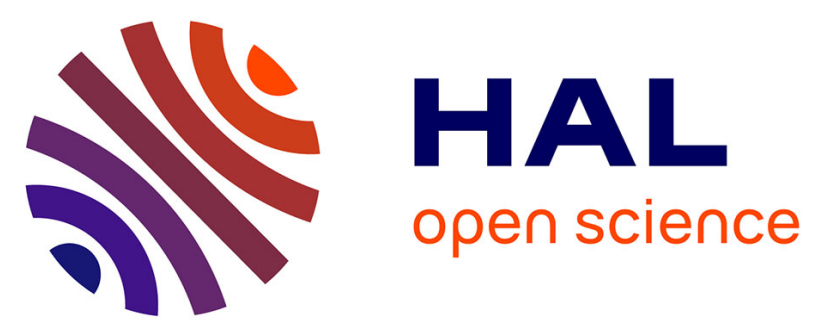

\title{
Inflammatory cytokines decrease viability and alter ganglioside profile in retinal pigment epithelium cells
}

\author{
Elodie A.Y. Masson, D. Dossarps, Olivier Berdeaux, Alain M. Bron,
} Catherine Creuzot Garcher, Lionel Brétillon

\section{- To cite this version:}

Elodie A.Y. Masson, D. Dossarps, Olivier Berdeaux, Alain M. Bron, Catherine Creuzot Garcher, et al.. Inflammatory cytokines decrease viability and alter ganglioside profile in retinal pigment epithelium cells. European Association for Vision and Eye Research (EVER) Congress, Sep 2013, Nice, France. Wiley-Blackwell, Acta Ophthalmologica, 91 (s252), 284 p., 2013, Abstracts from the 2013 European Association for Vision and Eye Research Conference. 10.1111/j.1755-3768.2013.F001.x . hal-02746885

\section{HAL Id: hal-02746885 \\ https://hal.inrae.fr/hal-02746885}

Submitted on 3 Jun 2020

HAL is a multi-disciplinary open access archive for the deposit and dissemination of scientific research documents, whether they are published or not. The documents may come from teaching and research institutions in France or abroad, or from public or private research centers.
L'archive ouverte pluridisciplinaire HAL, est destinée au dépôt et à la diffusion de documents scientifiques de niveau recherche, publiés ou non, émanant des établissements d'enseignement et de recherche français ou étrangers, des laboratoires publics ou privés. 


\section{- F001}

Inflammatory cytokines decrease viability and alter ganglioside profile in retinal pigment epithelium cells

MASSONEA (1), DOSSARPS D (2), BERDEAUX O (3), BRONA (2, 1)

CREUZOT C (2, 1), BRETILLONL (1)

(1) Eye and Nutrition Research Group, CSGA, UMR 1324 INRA, 6265 CNRS,

University of Burgundy, Dijon

(2) Ophtalmology, University Hospital, Dijon

(3) ChemoSens platform, CSGA, UMR 1324 INRA, 6265 CNRS, University of Burgundy, Dijon

Purpose Early stages of Age related Macular Degeneration (AMD) are characterized by dysfunction and degeneration of the retinal pigment epithelium (RPE) cells, which participate in the death of the overlying photoreceptors ultimately leading to loss of vision.Gangliosides (GG) make a wide and heterogeneous family of sialic-acidcontaining glycosphingolipids, composed of a sugar chain branched on a ceramide. They are major components of cellular membranes, particularly abundant in the brain and nervous tissue, including retina. While their developmental and neuroprotective actions have been demonstrated, their precise role in retinas function and its pathologies is still poorly understood.The present study aimed to investigate the role of $G \mathrm{G}$ in the response of RPE cells to inflammation, which is known as one of the pathophysiological features of AMD

Methods Cultured human RPE cells (ARPE19) were exposed to an inflammatory cytokine mixture (ICM): TNF- $\alpha$, IL-1 $\beta$ and IFN-g for 72 hours. Cell viability was assessed and GG were analyzed by Liquid Chromatography coupled with tandem mass spectrometry

Results ICM had deleterious effects on ARPE19 viability: cell number decreased by half between control and treated conditions. GM3 appeared to be the main GG class present in ARPE19 cells. Interestingly, ICM exposure was associated with modifications in the GM3 profile: relative amounts d18:1/16:0 species increased whereas those of d18:1/24:1 species decreased.

Conclusion Our observations suggest that GG might be implicated in ARPE19 cell response to inflammatory cytokines, although the precise biological role of the change in fatty acid profile of GM3 still needs to be clarified.

\section{- F003}

Chicken peptidylarginine deiminase type I and III are constitutively expressed in the retinal neuron

SHIMIZU A (1), HONDA T (2), KOIIMA T (2), KOHSAKA T (3),

TAKAHARA H $(1,2)$

(1) Department of Applied Life Science, United Graduate School of Agricultural Science, Tokyo University of Agriculture and Technology, Tokyo

(2) Department of Bioresource Science, College of Agriculture, Ibaraki University., Ibaraki

(3) Department of Applied Biological Chemistry, Faculty of Agriculture, Shizuoka University, Shizuoka

Purpose Peptidylarginine deiminase (PAD) is a post-translational modification enzyme that catalyzes the conversion of protein-bound arginine residues to citrulline residues in the presence of calcium ion. PAD genes are distributed generally throughout vertebrates. In chickens, three PAD genes have been identified and are orthologous to the mammalian genes encoding PAD1, PAD2 and PAD3, respectively. The expression levels and tissue/cellar location of each PAD under normal physiological conditions have not been elucidated as yet.

Methods CPAD1 or CPAD3 specific antibodies were prepared from rabbits immunized with a synthetic peptide and used for western blot analyses and immunohistochemistry assays. To determine the intracellular localization of chicken PADs in retina cells, immunoelectron microscopy was also carried out. Whether or not the deiminated proteins were produced in retinal tissues was also examined by immunohistochemistry using an anti-modified citrulline detection method.

Results We found that both cPAD1 and cPAD3 are expressed in the chicken retina CPAD1 was localized in the inner nuclear layer (INL) whereas CPAD3 was localized in the outer photoreceptor (OP). cPAD3 was present at especially high levels of detection in the lamella structure. Deiminated proteins were also detected in the INL and OP, suggesting that CPAD1 and CPAD3 function in the chicken retina under normal physiological conditions.

Conclusion Our findings suggest that chicken PAD1 and PAD3 play a homeostatic role in the chicken retina in governing sight.

\section{- F002 \\ Blue light toxic action spectrum on A2E-loaded RPE cells in sunlight normalized conditions}

BIGOT K (1), BARRAU C (2), GONDOUIN P (1), VILLETTE T (2), SAHEL JA (1) PICAUDS (1)

(1) Institut de la Vision, Paris

(2) Essilor, Charenton-le-Pont

Purpose Sunlight exposure is supposed to induce cumulative damage to the retina in retinal pathologies, such as AMD. The high energy visible spectrum between 380 $\mathrm{nm}$ and $500 \mathrm{~nm}$ (blue light) is incriminated. The goal of this study was to identify the spectrum of retinal toxicity induced by sunlight in physiological irradiance conditions.

Methods RPE cells incubated for 6 hours with $0,12.5,20$ and $40 \mu \mathrm{M}$ of A2E were exposed for 18 hours to $10 \mathrm{~nm}$ illumination bands with the first band centered at 390 $\mathrm{nm}$ and going up to $520 \mathrm{~nm}$. Light irradiances were normalized with respect to the natural sunlight reaching the retina after filtering by the eye ocular media. Six hours after light exposure, cell viability, necrosis and caspase-3/7 activity were assessed using the Apotox-Glo Triplex Assay.

Results A2E-loaded RPE cells presented fluorescent bodies within the cytoplasm with a similar spectrum to that of A2E. Exposure to the $10 \mathrm{~nm}$ illumination bands induced morphological changes associated to a loss in cell viability. Light toxicity was dependant of A2E concentration and was higher in the blue spectral range with maxima in a specific 30 to $40 \mathrm{~nm}$ bandwidth. In addition, caspase-3/7 activity, indicative of cell apoptosis, was highly induced by the same narrow range whereas necrosis was not significantly different to that of cells maintained in darkness.

Conclusion We described for the first time the precise spectrum of light toxicity in physiological irradiance conditions on an in vitro model of AMD. The 415-455 nm narrow spectral range generated the greatest phototoxic risk to RPE cells. This provides new information for designing selective protective filters, without disrupting visual and non-visual functions.

\section{- F004}

Does cyclodextrin affect penetration of diclofenac sodium through amniotic membrane?

RESCHM (1), MARSOVSZKY L (1), BUDAI-SZUCS M (2), SOOS J (3) BERKO SZ (2), SIPOS P (2), NEMETHJ (1), SZABO-REVESZ P (2), CSANYIE (2)

(1) Department of Ophthalmology, Semmelweis University, Budapest

(2) Department of Pharmacological Technology, Szeged

(3) Department of Ophthalmology, University of Szeged, Szeged

Purpose To investigate permeability of amniotic membrane (AM) to diclofenac sodium containing eye drops with or without cyclodextrin (CD)

Methods Cryopreserved AM pieces on cellulose acetate filter membranes were mounted in the previously established vertical Franz-diffusion cell system equipped with autosampler. In vitro penetration of two commercially available eyedrops containing $0.1 \%$ diclofenac sodium was examined. Voltaren Ophtha CD (VO, with $\mathrm{CD}$ ) and Uniclophen (UN, without $\mathrm{CD}$ ) were compared. Drug release was determined by quantitative absorbance measurement carried out with a high performance liquid chromatography (HPLC).

Results The initial two hours, release of diclofenac from $\mathrm{VO}$ was lower than penetration of diclofenac from UN. At 30 minutes only 6.6\% of diclofenac penetrated AM from VO vs $11.5 \%$ from UN. At 2 hours difference between two eyedrops was not siginificant (25.69\% for $\mathrm{VO}$ and $27.39 \%$ for $\mathrm{UN}$; $\mathrm{p}>0.05$ ). After two hours, greater concentration of $\mathrm{VO}$ could be measured in the acceptor phase than that of UN and this difference remained significant over the study period. Seven and half hour after instillation we detected $56.26 \%$ for $\mathrm{VO}$ versus $35.62 \%$ for UN of baseline concentrations

Conclusion Drug penetration of diclofenac sodium was affected by CD. Until 120 minutes following instillation, $\mathrm{CD}$ decreased drug release from eyedrop containing $\mathrm{CD}$ compared to eyedrop without $\mathrm{CD}$. After 2 hours, however drug penetration became significantly greater from solution with CD compared to solution without CD. 